\title{
From medical tourism toward a space for transnational care: the case of Libyan patients in Sfax (Tunisia)
}

Betty Rouland, Mounir Jarraya and Sébastien Fleuret

\section{(2) OpenEdition}

Journals

Electronic version

URL: http://journals.openedition.org/rfst/801

DOI: $10.4000 /$ rfst.801

ISSN: 2492-3672

Publisher

Espaces et SOciétés (UMR 6590)

Electronic reference

Betty Rouland, Mounir Jarraya and Sébastien Fleuret, "From medical tourism toward a space for transnational care: the case of Libyan patients in Sfax (Tunisia)", Revue francophone sur la santé et les territoires [Online], Tourism, Mobility and Health, Online since 25 October 2016, connection on 06 April 2021. URL: http://journals.openedition.org/rfst/801 ; DOI: https://doi.org/10.4000/rfst.801

This text was automatically generated on 6 April 2021.

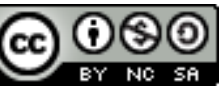

La Revue francophone sur la santé et les territoires est mise à disposition selon les termes de la Licence Creative Commons Attribution - Pas d'Utilisation Commerciale - Partage dans les Mêmes Conditions 4.0 International. 


\title{
From medical tourism toward a space for transnational care: the case of Libyan patients in Sfax (Tunisia)
}

\author{
Betty Rouland, Mounir Jarraya and Sébastien Fleuret
}

1 This paper focuses on the triptych "health-tourism-territory" analyzing the logics of the development of private health services in the Tunisian city of Sfax and the modes of utilization of care by Libyan patients since the Arab revolutions in 2011. This phenomenon is based on geographical proximity and started during the 1990s, whereby a combination of multidimensional factors promoted the growth of an original sector, making Tunisia a leading destination for medical tourists:

- An United Nations embargo on Libya provoked the first medical tourist flows,

- Opening of the borders and free movements with the abolition of visas,

-Availability of medical staff in Sfax, due to an existing University Hospital,

- High quality and affordable health services,

- Infrastructures such as direct flights to Tripoli - also used by Tunisian doctors practicing in Libya.

Despite the geopolitical instability in the region since 2011, medical tourism has had an important impact on the urban landscape of Sfax, most notably in form of a new economic opportunity for a city that has been marginalized as regards the development of tourism infrastructure.

3 This paper provides a detailed analysis of the recent changes of a phenomenon understudied through a geographical lens, addressing in particular its local impacts and the magnitude of urban reconfigurations since the Arab revolutions.

4 Facing a lack of data and an instable geopolitical situation, with armed conflict in Libya, the methodology combines a qualitative survey amongst Libyan patients $(n=205)$ in four private clinics in the city of Sfax as well as semi-structured interviews conducted with medical staff. In addition, we completed the study with an analysis in situ of the urban 
morphology around the private clinics where transformation and reconfiguration processes take place through new investment dynamics (new commercial and residential areas) with high impact on the land and real estate market.

5 On the one hand, the findings show that the chaos in Libya as well as the geographic proximity to Sfax push the (para)medical staff to invest in the private health sector considering "the Libyan market instable but as an expanding niche market". The number of private polyclinics raised from three to 12 between 1998 and 2011 while other clinics are ongoing projects.

On the other hand, the findings point to the growth and the diversification of patients' profiles (networks, recourses, needs of care, etc.). The war in Libya is increasing the vulnerability of the population regarding the accessibility of care in Libya. Spatial reconfigurations, such as new city planning (medical, residential, commercial) and regional circulation flows (patients, transports, assurances systems, etc.), are the expression of an emerging transnational space of care. The political context as well as the impoverishment of the patients leads us to reconsider the definition of "medical tourism" in this context and to question the sustainability of the related investments in Sfax, given its dependence on Libyan patients.

\section{Polyclinics in Sfax}

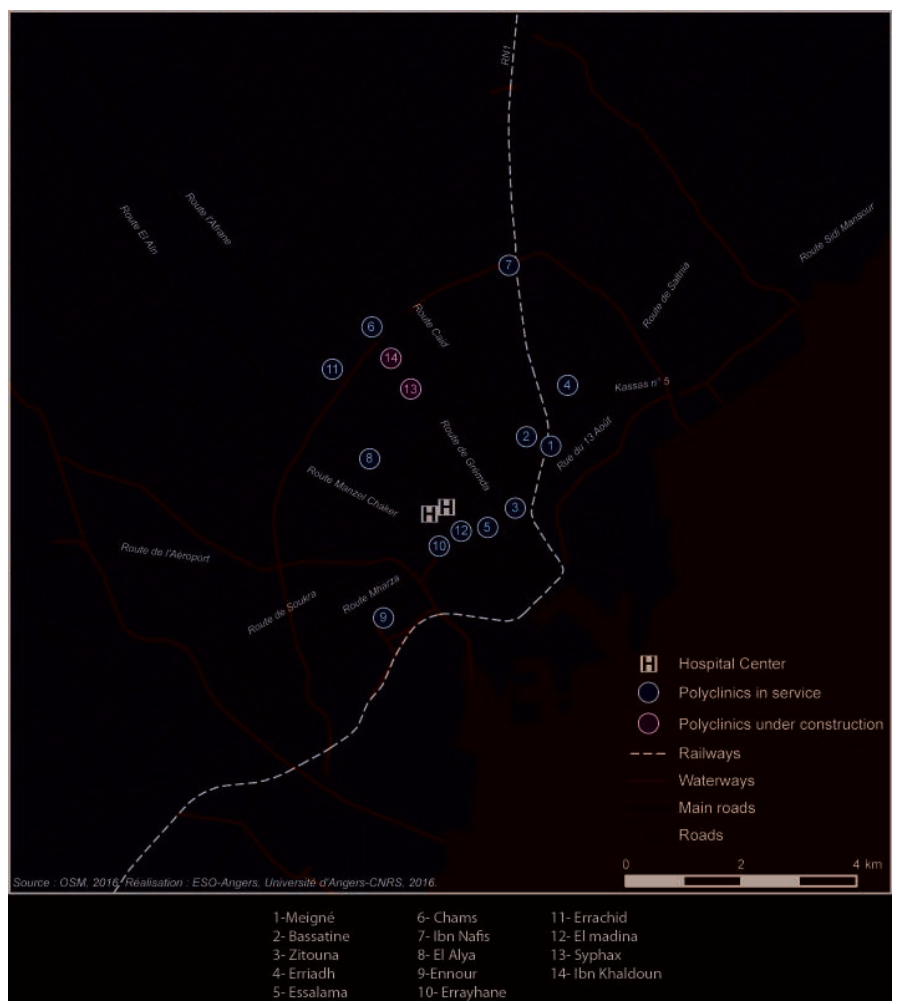


INDEX

Geographical index: Libya, Tunisia, Sfax

Keywords: medical tourism, Lybian patients, private health services, globalization, local development, transnational space

\section{AUTHORS}

\section{BETTY ROULAND}

Chercheur Post-doctoral, Institut für Humangeographie Goethe - Universität Frankfurt/Main (Allemagne)

\section{MOUNIR JARRAYA}

Enseignant-chercheur, Laboratoire Syfacte, Université de Sfax (Tunisie)

\section{SÉBASTIEN FLEURET}

Directeur de recherche CNRS UMR ESO 